\title{
- Basic Research
}

\section{Effect of Implementing Evidence- Based Guidelines on Lifestyle Modification for Adult Patients with Renal Stone Undergoing ESWL Procedure}

\author{
Doaa A.N. Abdelwahab ${ }^{1}$, Sanaa M. Alaa El-deen ${ }^{2}$, Alice E. Rezian ${ }^{3}$, Anis Elhkouly ${ }^{4}$ \\ 1(Lecturer, Medical-Surgical Nursing, Faculty of Nursing, MTI University, Egypt),2(Professor, \\ Medical-Surgical Nursing, Faculty of Nursing, Alexandria University, Egypt)3(Professor, \\ Medical-Surgical Nursing, Faculty of Nursing, Alexandria University, Egypt)4(Assistant \\ Professor, Medical-Surgical Nursing, Faculty of Nursing, Alexandria University, Egypt) \\ e-mail: doaa.abdelwahab@yahoo.com
}

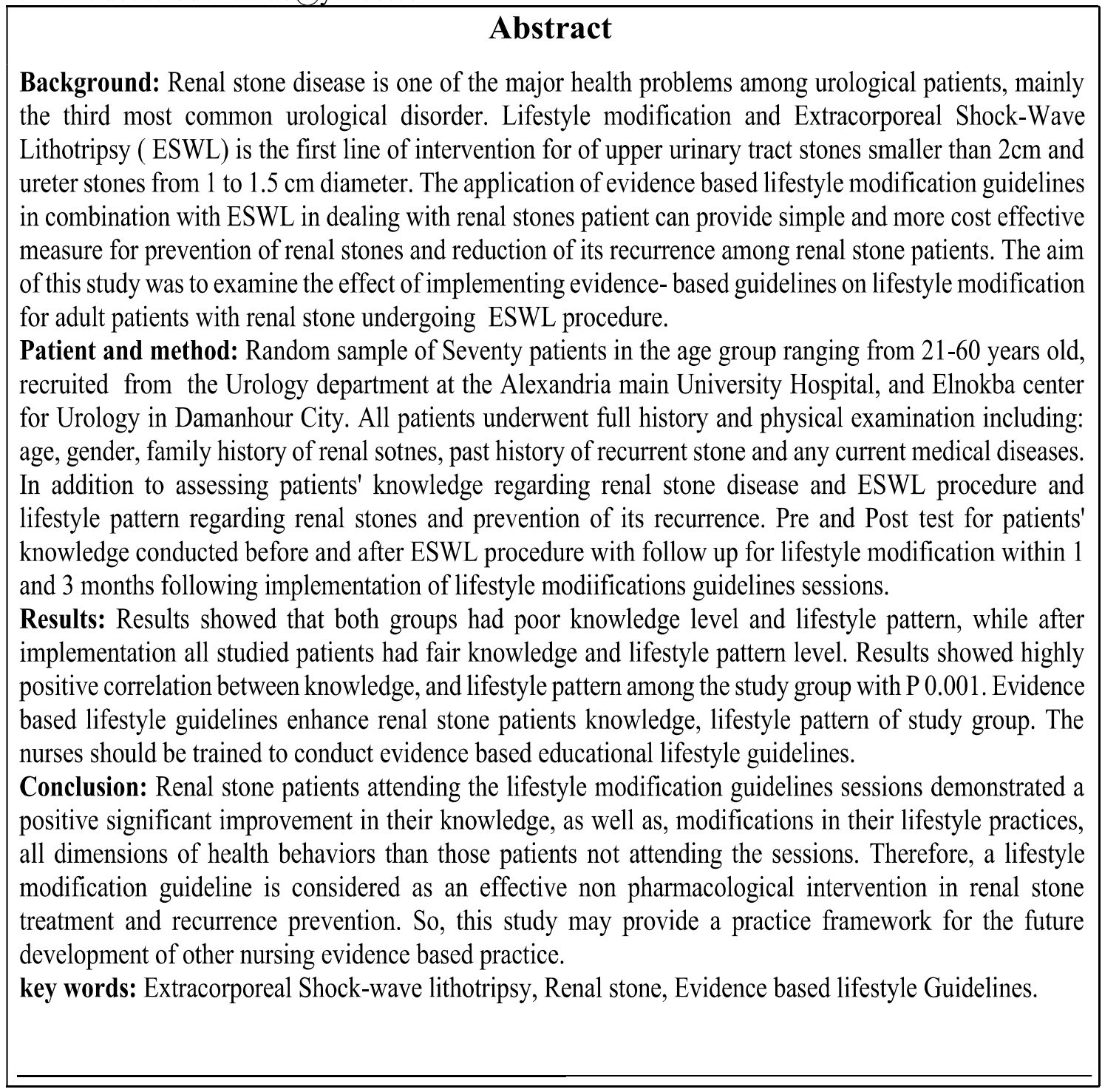

EJNHS Vol.2, No.1 


\section{Introduction:}

Renal stone disease is one of the major health problems among urological patients, mainly the third most common urological disorder, affecting both male and female and one of the most common kidney disorders especially in our locality ${ }^{(1)}$. It can be debilitating and painful condition, where recurrent kidney stone formation can result in decreased quality-of life (QOL), interruptions in work and social commitments, expanded use of medical services, increased hospitalization rate, and even kidney damage, or infection with poor health outcomes, and increasing financial burden ${ }^{(2)}$

Prevalence is estimated at $3 \%$ of all individuals and affects up to $12 \%$ of the general population during their lifetime. The overall incidence of renal stone disease is reported to be increasing, which is considered mainly related to changes in lifestyle practices. The incidence rate also varies with geography, climate, and seasonal factors, with a higher incidence in hotter, drier environments, related to the greater risk of dehydration. ${ }^{(2)}$.

Moreover, the most classic presentation of a renal stone is acute, sudden, severe, colicky flank pain radiating down the abdomen to the groin or scrotum that may be associated with urinary urgency, frequency, dysuria, and hematuria. In patients with a renal stone, the primary goal of management is to detect complications and prevent or decrease recurrence. Lifestyle modification is, therefore, the first line of intervention for all patients to improve their health outcomes and prevent recurrence ${ }^{(3)}$.

Therefore, patients should be informed about the different lifestyle modification which help to decrease the risk of recurrences and other various modalities for renal stone management, which includes medical dissolution therapy, ureteroscopy (URS), percutaneous nephrolithotomy (PCNL), and extracorporeal shock waves lithotripsy (ESWL). Extracorporeal shock wave lithotripsy remains the sole minimally invasive and effective surgical management modality for renal stone disease ${ }^{(4)}$.

Hence, lifestyle practices can contribute to the risk of renal stone formation; addressing these practices adequately can provide simple and more cost effective measure for prevention of renal stones and reduction of its recurrence among renal stone patients ${ }^{(5)}$. Therefore, lifestyle modification related to dietary habits, fluid intake, stress management, weight reduction, physical activity, follow up and compliance with therapeutic regimen are particularly an important behavioral strategy for self-management of renal stone ${ }^{(6)}$. 
Evidence-based nursing practice has been the gold standard for nursing care delivery. It is defined as the integration and application of the best possible research results which is not only a definitive role for nurses practicing, but is also a major contribution to the science of nursing.To promote health, prevent diseases and ameliorate symptoms of existing diseases, individuals must have a learning ability to meet their needs; otherwise they need to reach available sources in order to enhance their knowledge. They also, need to learn how to modify their lifestyle pattern ${ }^{(7)}$.

The European Association of Urology (EAU) stated that lifestyle modification is the first line for prevention and treatment of renal stones among the adult population. It is advised as initial therapy for most of renal stone patients. The EAU also provided global recommendations related to lifestyle modification for treatment and prevention of renal stone disease as a comprehensive approach that includes specific dietary recommendations as consumption of healthy diet, increasing daily activities and exercise, selfmonitoring for signs and symptoms of illness, seeking periodic health evaluations, smoking cessation, alcohol restriction, adapt effectively with stressful situation, taking prescribed medications, and performing other therapeutic and preventive measures ${ }^{(8)}$.

Nurses, therefore, must be a cornerstone in the care and education of adult patients with renal stone disease for a successful treatment outcome, improving QOL and preventing the disease complications and its recurrence for those patients through assessment, planning, implementation and evaluation of educational guidelines for helping patients to learn or relearn healthy lifestyle practices, as focusing on the patient's response to health and illnesses rather than on the disease itself.

\section{Aim of the study:}

The aim of this study was to examine the effect of implementing evidence- based guidelines on lifestyle modification for adults.

\section{Research hypothesis:}

Adult patients with renal stones undergoing extracorporeal shock wave lithotripsy, who received the proposed lifestyle modification guidelines, experienced more improvement in their knowledge and modification in their lifestyle practices, than those patients who did not. 
Material and methods:

Research Design: A quasi experimental design was used in the present study.

Setting: The study was conducted at the Eswl Unit of the Main Alexandria University Hospital.

Subjects: This study comprised a random sample of 70 adult patients admitted to the above-mentioned settings and diagnosed with renal stone undergoing the ESWL procedure. The study subjects were divided randomly into two equal groups; a study group, consisting of 35 adult patients who received the routine hospital care and the planned evidence-based guidelines on lifestyle modification regarding renal stones prevention, and a control group, consisting of 35 adult patients who received the routine hospital care only.

\section{Tools for data collection:}

Tool I: Renal Stone Patients' Knowledge Structured Interview Schedule; this tool was developed by the researchers in Arabic language, it contains two parts:

Part I: Patients' Clinical Data: This part of the tool included information related to; past and present medical history, and chief complaints.

Part II: Renal Stone Patient Knowledge and Learning Needs, Structured Interview Schedule:

It was used to assess baseline knowledge of patients about the disease and to identify patients learning needs as pre-requisites for planning the lifestyle modification guidelines. Additionally, socio-demographic data tool was attached; this was developed by the researcher based on relevant literature and included, socio-demographic characteristic such as name, age, sex, marital status, educational qualification, occupation as well as the socio-economic particulars such as family history of renal stone, total monthly family income. In addition to, personal habits such as smoking, taking analgesics, medications, normal recipes and alcohol intake. In addition to, weight, height and body mass index (BMI), 


\section{Tool II: Renal Stone Patients' Health Promoting Lifestyle Practices Structured Interview Schedule:}

this tool was used to assess the renal stone patients' healthy lifestyle practices. It consisted of one part: Renal Stone Patients' Health Promoting Lifestyle Practices. It was used to measure respondents' healthy lifestyles.

\section{Procedures of the study:}

This study was conducted through four consecutive phases: assessment, planning, implementation, and evaluation.

- Assessment phase: This phase aimed to assess the studied patients' characteristics, clinical data, and patients' knowledge related to renal stone disease, ESWL procedure and lifestyle pattern of the study and control groups.

- Planning phase: the contents of lifestyle modification guidelines for renal stone patients were formulated based on the guidelines of the American and European urological association, relevant literatures.

- Implementation phase: An instructional media was used; it included the guidelines handout and audiovisual materials.

- Evaluation phase: the evaluation phase was emphasized on estimating the effect of life style modification guidelines on patients' knowledge, lifestyle practices of the study group. The post test was conducted for study and control groups after 1 and 3 months of implementation phase.

\section{Ethical considerations:}

- Written approval to carry out the study was obtained from ethical committee of the faculty of nursing.

- Oral consent of the patients to participate in the study was obtained.

- Privacy of the patients was maintained.

- Confidentiality of the collected data was secured. 


\section{Results:}

\section{Socio-demographic characteristics}

Table (1): Illustrated distribution of the studied sample according to their socio-demographic characteristics. The socio-demographic background of the present study showed that, the mean age of the study group was $39.23 \pm 10.79$ years, while the mean age of the control group was $41.5 \pm 11.9$ years. Females were more prevalent in the studied sample. The majority of patients in the study and control groups were married. Illiteracy was prevailing among more than one third of patients in the study and control groups. More than one third of the study and control groups were housewives. Additionally, the majority of studies, patients in both groups were housewives and manual workers, came from rural areas, did not have enough monthly income and there were no significant differences in socio-demographic characteristics between the two groups.

\section{Effect of the educational session guidelines on patients' knowledge and lifestyle pattern:}

Table (II): shows the effect of the educational session guidelines on patients' knowledge in this table the findings generally point to a great lack of adult patients' knowledge about renal stone disease, ESWL procedure, and lifestyle modification for recurrence prevention prior application of the educational guideline and highlighted a significant improvement in all these parameters. The total mean score of knowledge before sessions' implementation were $8.81 \pm 5.1$ for the study group and $7.00 \pm 4.37$ for the control group, with no statistically significant differences between both groups, where the highest proportion of the studied patients was scored as poor health-related knowledge. At the post-intervention phase, the current study showed that, there was a significant improvement in patients' knowledge, and this persisted during the follow-up period in comparison with the control group.

Table (III): shows the effect of lifestyle modification guideline on lifestyle pattern of study and control group before, immediately and post 3 months. The current study revealed obviously inadequate self-management behaviors and lifestyle practices in relation to diet, fluid intake, physical activity, measures to reduce stress, awareness about smoking dangers, weight reduction, and periodic medical follow up before the implementation of the guidelines reflected by poor practice scores among all studied patients. 
After implementation of lifestyle modification guidelines sessions, the results of the current study showed that, the total and all dimensions of lifestyle patterns, including fluid intake, healthy dietary habits, physical activity \& exercises, compliance with medications, weight monitoring, stress management, and periodic follow-up show a significant improvement in the study group compared with the control group.

\section{Relationships between demographic variables, lifestyle pattern and the total knowledge score knowledge:}

Table (IV): The relation between socio - demographic characteristics of the study group and the total knowledge scores before and after the lifestyle modification sessions: Although, it appears from the table that males obtained a higher mean score regarding knowledge rather than females pre and post implementation of lifestyle modification sessions, the gender of the study group did not affect significantly on the total knowledge scores before and after 3months follow up. A significant relation was found between level of education, marital status, employment status, area of residence, working place and average monthly income of patients in the study group and their knowledge scores only before implementation of lifestyle modification sessions.

Table (V): this table illustrated the relation between the relation between socio-demographic characteristics of the study group and total lifestyle mean scores before and after implementation of the lifestyle modification guidelines. It can be observed from this table that, there was no relation found between socio demographic characteristics and lifestyle patterns except in gender immediately post lifestyle, in which the adult males obtained a higher score than the adult females $(\mathrm{P}=0.001)$, and employment status which affects significantly on the lifestyle patterns post and after 3 months the sessions where $\mathrm{P}$ values were 0.001 and 0.045 , respectively.

Table (VI): This table illustrated the correlation between study group's knowledge and their lifestyle scores at immediately post and at 3 months after the sessions. The table revealed that, there was a significant positive correlation between total and all items of knowledge scores and total lifestyle scores immediately post lifestyle modification. 


\section{Discussion:}

Rising incidence and recurrence rates of renal stone disease have focused attention on risk factors, especially lifestyle risk factors associated with the recurrence of renal stones. There is an increasing body of evidence that following a healthy lifestyle, including appropriate diet, adequate fluid intake, satisfactory physical activity level, nonsmoking and a healthy weight can provide substantial health benefits for renal stone patients ${ }^{(9)}$.

Findings of the current study ensured that health teaching, which is one of the most important nursing responsibilities, had a significant impact on lifestyle modification of renal stone patients undergoing ESWL procedure, and on improvement of patients' knowledge about preventing newly urinary tract stones.

In relation to age group, the present study findings revealed that the highest percentage of the study subjects were in the age group of $30<40$ years. These come in agreement with Patel et al. (2014) ${ }^{(10)}$, Naeem et al ${ }^{(11)}$, who reported that, the incidence of renal stone disease is increasing in people age groups (31-40). While coming into contradiction with Knoll (2011) ${ }^{(12)}$, who stated that the incidence of renal stone disease is increasing in people age groups (40-60) years. The possible explanation of these findings may be related to the strong correlation between age and chronicity of renal stone disease and, age is considered a risk factor for renal stone formation, where the earlier onset of the first episode, the more likely a person will be a multiple stone former.

Concerning gender; although, renal stones were usually described as more frequent in men, a change in the prevalence of gender has been reported during the last decade. The present study revealed that renal stone disease affected females more than males. This may be attributed to changes in dietary habits and lifestyle risk factors such as obesity increased stressful life situation which has more prevalence and influence on females rather than males and leads to disease as, hypertension and diabetes mellitus which aggravating renal stone formation. The same finding was reported in a study carried out by Mawhoob et al. (2014) ${ }^{(13)}$. On the other hand, Shamsuddeen et al. (2013) (14), found that, both males and females were similarly affected by renal stone disease in the ratio 1:1. While, Naem et al. (2013) ${ }^{(11)}$, reported that, renal stones were more frequent in men than in women, with a male to female ratio 5:1.

Patient level of education play important role in identifying the risk factors for recurrent urinary stone and preventive measures for stone formation. Regarding this, the present study revealed that illiteracy was prevailing among more than one third of patients in the study subjects. This may be related to the fact that the majority of the study subject came from rural areas with low socioeconomic status, interested in manual and farm work. It also, may be related to the association between illiteracy and many false practices and unhealthy behaviors that may predispose patients to renal stone disease, especially who have low levels of education or no knowledge about their illness in 
relation to causes, precautions and methods of prevention. This was in the same line with Devraj et al. (2015) ${ }^{(15)}$, who reported that, the highest proportion of studied patients were illiterate and concluded that, low health literacy (HL) contribute to poor self-management of renal stone disease and poor kidney function.

Concerning the residence area, the results of this study revealed that, the highest percentage of the studied patients were living in rural areas. This may be explained by lack of education, low socioeconomic status, poor sanitation, and poor media in rural areas which place people at higher risk for renal stone disease. Also, people living in rural and remote areas may have poorer health status and face greater health risk factors than people living in urban areas. This is supported by the findings of Gamal et al. (2010) ${ }^{(16)}$, who found that the majority of the studied sample lived in rural areas.

In relation to economic status, the present study finding revealed that, the majority of study patients' monthly income was not enough. This result may be related to increased poverty and unemployment in Egypt and especially in many rural regions. This comes in accordance with, Glasheen, and Anderson (2016) ${ }^{(17)}$, who stated that, lower socioeconomic status was a risk factor for renal stone incidence and recurrences, and that, highest percentage of the patients were from lower middle class. While, come in contradiction with Shaaban B (2014) ${ }^{(18)}$, who showed that, more than half of the studied patients' monthly income was enough .

As regards occupation and working in hot climates; the present study showed that the highest percentages of the study subjects were housewives followed by practical workers and was working indoors, this may be related to the high prevalence of females and that most of study subjects came from rural areas. These, also, may be justified by spreading of quackery and unhealthy traditions among rural housewives and that, exposure to high temperatures increase perspiration, which may result in dehydration and concentrated urine, which in turn promotes increased urinary crystallization and change $\mathrm{PH}$ of urine so prepare good media for stone formation, especially among practical workers, mechanic, construction workers, drivers, farmers or other jobs exposed to high temperatures compared with those working in normal temperatures ${ }^{(19)}$

These findings come into agreement with Peacock et al. (2013) (19), who discussed that, renal stone incidence and occurrence is more common among housewives, and manual workers.

Regarding patients' knowledge, at the pre-intervention phase; the findings generally point to a great lack of adult patients' knowledge about renal stone disease, ESWL procedure, and lifestyle modification for recurrence prevention prior application of the educational guideline and highlighted a significant improvement in all these parameters. The total mean score of knowledge before sessions' implementation were $8.81 \pm 5.1$ for the study group and $7.00 \pm 4.37$ for the control group, with no statistically significant differences between both groups, where the highest proportion of the studied 
patients was scored as poor health-related knowledge. These may be related to the high proportion of illiterate patients who came from rural areas or that; the majority didn't receive adequate information from healthcare personnel. As well as it could be due to limited time of health care providers or lack of awareness of the need to do so.

These findings come in accordance with studies conducted by Pavithra. (2010) (20), who revealed a lack of knowledge and awareness among the local public and adult renal stone patients, about renal stones as an important health problem and revealed that, lack of knowledge among the causes of non-compliance with prevention guidelines and recommended that, further education is needed for renal stone patients. On the other hand, Bakunts (2011) ${ }^{(21)}$, emphasized that, studied patients had a good knowledge level, and discussed that, despite the higher knowledge the study participants generally had about renal stone disease prevention, it was not enough to change the behavior of the kidney stone formers to prevent future formation of kidney stones.

At the post-intervention phase, the current study showed that, there was a significant improvement in patients' knowledge, and this persisted during the follow-up period in comparison with the control group. This is in accordance with Mohamed (2015) (22), which concluded a significant increase in the knowledge level among the studied patients post program and in follow up after 3 months compared to preprogram evaluation. Additionally, Pietrow and Preminger, (2011) (23), stated that, patient education is the most helpful approach for preventing recurrences of urinary tract stone.

After implementation of lifestyle modification guidelines sessions, the results of the current study showed that, the total and all dimensions of lifestyle patterns, including fluid intake, healthy dietary habits, physical activity \& exercises, compliance with medications, weight monitoring, stress management, and periodic follow-up show a significant improvement in the study group compared with the control group. This improvement may be attributed to the fact that, the knowledge acquisition during the lifestyle modification sessions plays an essential role in motivating the renal stone patients in adopting healthy lifestyle to enhance stone clearance and prevent its recurrence.

This was matched with Mohamed (2015) ${ }^{(22)}$, who concluded that, after the implementation of the educational program for the study group, patient's health practices were significantly improved, and Ylmaz and Turgut (2011) ${ }^{(23)}$ who stated that, patient education regarding healthy practices is the most helpful approach for preventing recurrences of urinary tract stone and showed significant improvement in patients' practices. Moreover Pietrow and Preminger, (2011) ${ }^{(23)}$, reported that, patient education and counseling are vital roles of nurse for effective care concerning; causes and risk factors for stone formations, ESWL procedure, its advantages, precautions to be followed prior, during and after the ESWL procedure as well healthy practices. 
In relation to adherence to recommended daily fluid intake guidelines, fluid intake seems to be a highly correlated factor with renal stone prevalence and recurrence. In this respect, the present study revealed statistically significant improvement among the study group concerning their daily fluid intake. Similar findings were reported by Bos et al. (2014) ${ }^{(25)}$, who found marked improvement in adopting healthy behaviors related to fluid intake among study patients and concluded that, an increase in fluid intake remains the strongest recommendation in renal stone prevention.

Also, the present study revealed statistically significant improvement among the study group regarding their health dietary habits which suggested that diet playing a major role in stone formation and recurrence prevention. These results are also consistent with a study carried out in Egypt by Mohamed (2015) ${ }^{(22)}$, who observed that, those receiving the intervention have a greater, dietary recommendation adherence, and stone clearance as compared with the control group through follow up period..

On studying the relation of different socio-demographic characters of the study population on acquiring knowledge and practice, many factors may affect the result of the guidelines session or ESWL for the studied sample. These factors may be related to demographic characteristics of the patients such as age, level of education, and income, or employment status or related to stone characteristics. The current study reported a significant relation between level of education, marital status, employment status, area of residence, working place and average monthly income of patients in the study group and their knowledge acquisition score only before implementation of lifestyle modification sessions.

While, in relation to their adoption of healthy behaviors, there was no relation found between socio - demographic characteristics and lifestyle patterns except in gender immediately post lifestyle, in which the adult males obtained a higher score than the adult females $(\mathrm{P}=0.001)$, and employment status which affected significantly on the lifestyle patterns post and after 3 months the sessions where $\mathrm{P}$ values were 0.001 and 0.045 , respectively.,

In this respect, Abid (2014) ${ }^{(26)}$, found that; age and sex have no effect on patient knowledge, practice or ESWL success rate. Again, Mohamed (2015) ${ }^{(22)}$, showed that, sex and history of chronic diseases had no effect on stone free rates while; knowledge, age, place of residence, education, stone location, size, number of stones, and history of recurrent urolithiasis had a significant effect on patient knowledge, practices or stone free rates by ESWL among the studied sample.

The present study revealed that, both knowledge and practices score of the study group correlated significantly and positively to all dimensions of health behaviors only at first evaluation period. This finding explained by the fact that, the individuals have higher knowledge are more likely to have a higher cognitive function and better comprehension capability so that, they might understand the necessity of lifestyle 
changes and more motivated to perform health behaviors early after the implementation of health guidelines sessions than after three month evaluation.

This finding was congruent with Shaaban (2014) ${ }^{(18)}$, who showed high statistically significant differences between patients' knowledge mean scores and their health practice about high salt diet, decrease fluid intake, especially water and urinary tract infection as causes of renal stones and patients' perception about the occurrence of renal stones. Furthermore, this significance was supported by Weinman and Keith (2012) ${ }^{(27)}$, who reported that, the patient constructs a cognitive representation of his or her illness that, guides behavior, beliefs about the cause of illness. In this respect, $\boldsymbol{A} \boldsymbol{b} \boldsymbol{u}$ Bakari et al. (2011) ${ }^{(28)}$, reported that, patients' knowledge about the cause of illness can comprise awareness about the general precaution, treatment and lifestyle practices.

Finally, this study emphasizes the role of integrating education in a management of renal stone disease by all health professionals with including nurse, where acquiring knowledge and skills can lead to changes in human behavior that are necessary for the maintenance or improvement of health. So, depending on the previous data, evaluating the effect of lifestyle modification guidelines of knowledge and practices of adult regarding the renal stone disease will help the nursing personnel enhance patients' awareness and takes proper precautions to prevent the occurrence of disease, to reduce the morbidity and mortality rate caused by renal stone and its complications and to follow necessary prevention strategy.

\section{Conclusion:}

In view of the study results and research hypothesis, it can be concluded that; renal stone patients attending the lifestyle modification guidelines sessions demonstrated a positive significant improvement in their knowledge, as well as, modification in their lifestyle practices regarding (renal stone disease, ESWL procedure, and all dimensions of health behaviors), than those patients did not attend the sessions, which is indicated to minimize recurrence rate. Importantly, the results from the present study can be applied in the clinical settings with the goal of reducing the likelihood of recurrent stone formation. 


\section{Based on the findings of the present study, we can recommend:}

1. Recommendations for Nursing Practice:

- Evidence based guidelines should be developed with the cooperation of team of urology department and nursing specialists and the approval form hospital administration and be integrated within the plan of care for renal stone patients on different aspects of lifestyle modification to treat and prevent renal stone formation.

- Establishment of an educational unit for renal stone patients.

- Follow up visits either to the urology clinic or through home visits or telephone visit is important in order to evaluate the progress of patients' condition and motivate them to adopt a healthy lifestyle to prevent complications or recurrence and QoL.

2. Recommendations for Nursing research:

- More studies are needed to evaluate the effectiveness of long term follow up of lifestyle modification guidelines on renal stone recurrence and QoL. 
Table (I): Frequency distribution of the study and control group, according to their socio-demographic characteristics:

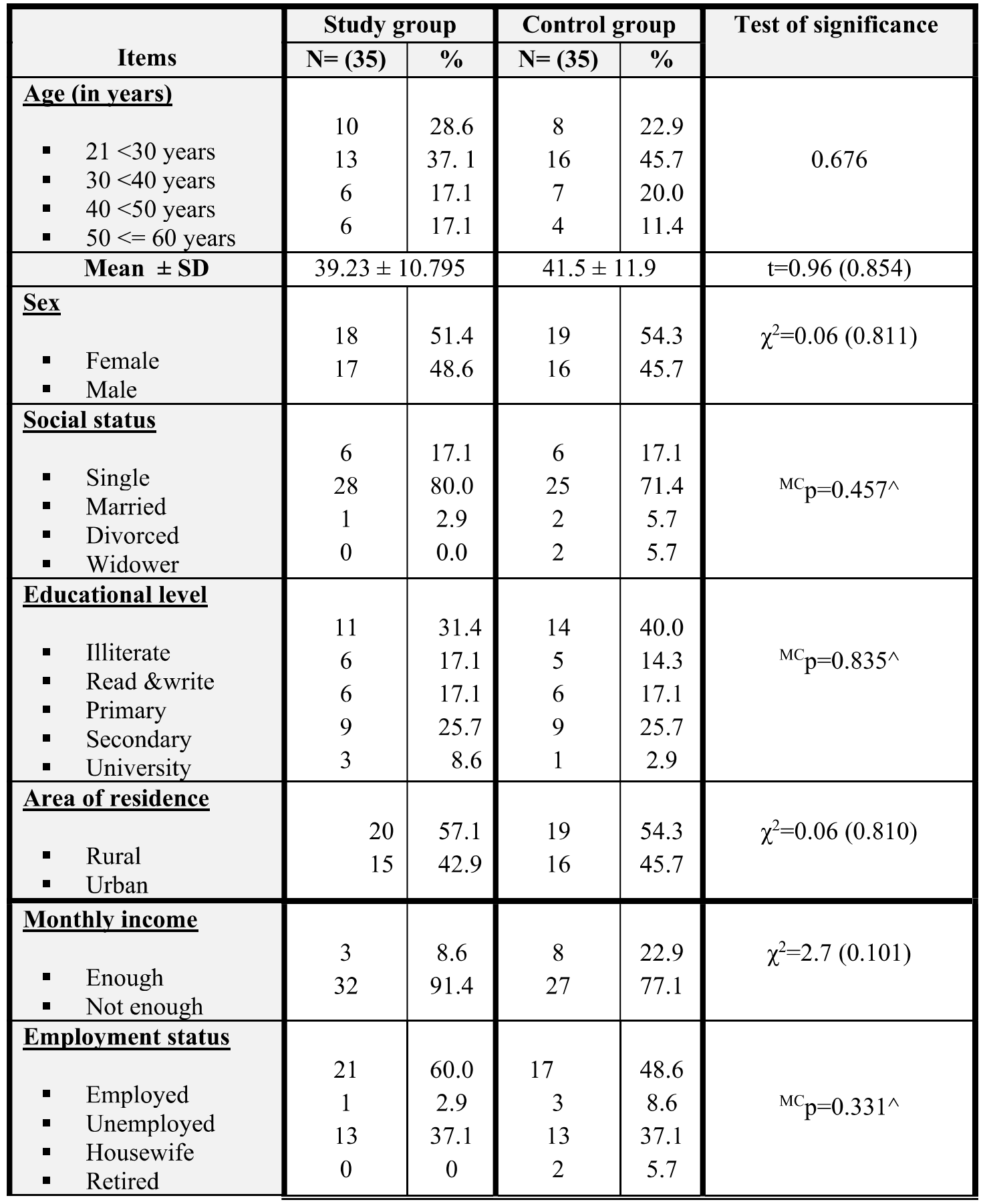


Table (I): Cont.:

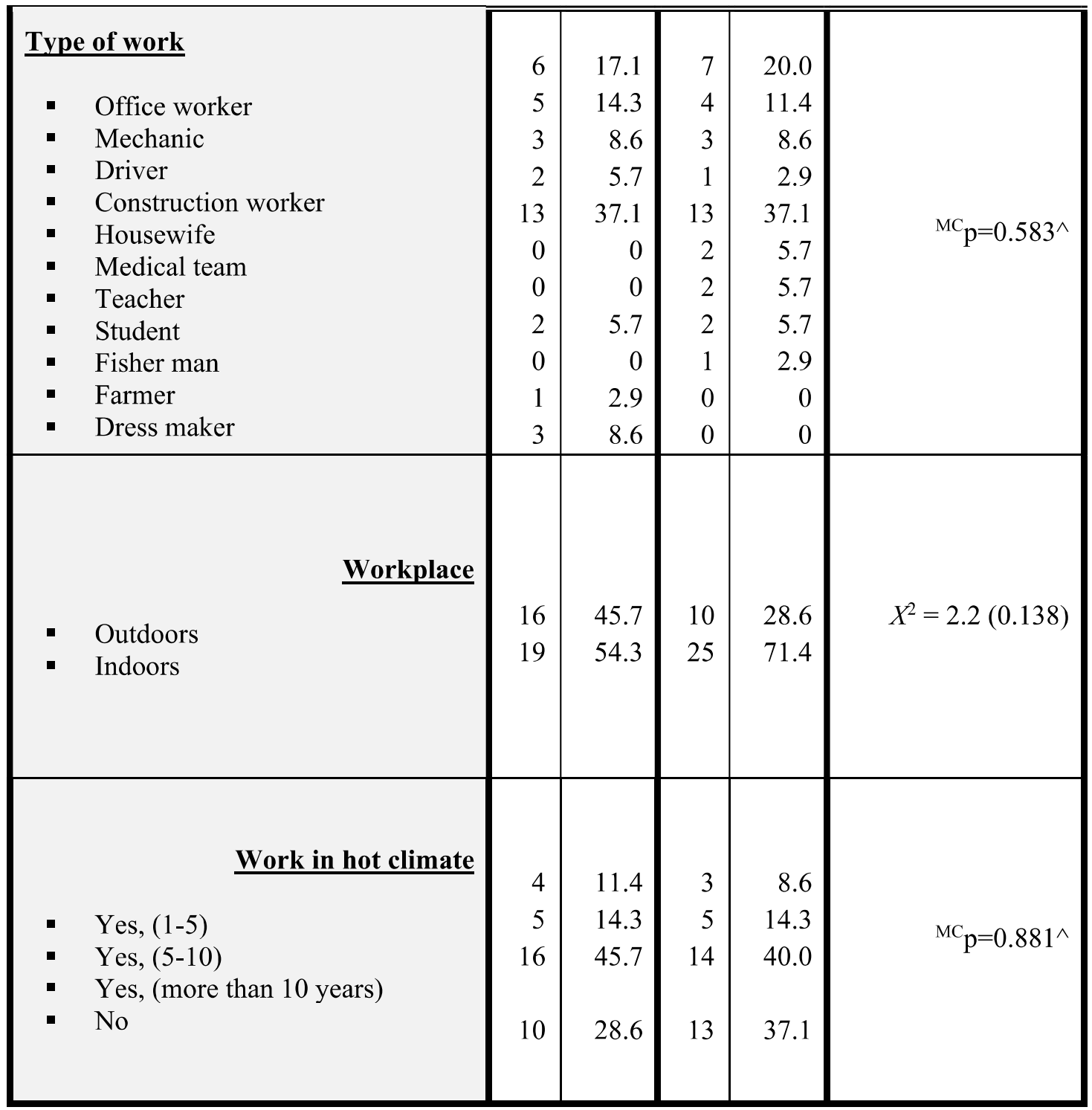


Table (II): Frequency distribution of the study and control group according to their risk behaviors (smoking, caffeine consumption, alcohol intake and over the counter drugs):

\begin{tabular}{|c|c|c|c|c|c|c|c|}
\hline \multicolumn{3}{|c|}{ 질 } & & ' & & \multicolumn{2}{|c|}{. } \\
\hline \multirow{6}{*}{$\begin{array}{l}\text { 영 } \\
\text { 형 } \\
\text { 형 }\end{array}$} & \multirow{2}{*}{ 壳 } & $\therefore$ & 용 & ᄋ̊ㅇㅇ & & 8̊ㅇㅇㅇㅇ & தீㅇㅇ \\
\hline & & 운 & $m 0$. & 0 & & $\approx 0$ & 0 \\
\hline & \multirow{2}{*}{ 亡̆. } & $\therefore$ & 8̊ㅇㅇㅇ & 今े & & 융 & 8̊ \\
\hline & & 운 & mo & 0 & & mo & 0 \\
\hline & \multirow{2}{*}{ 竞 } & $\approx$ & த̊ㅇㅇㅇㅇㅇ & 웅 & & 융 & 웅 \\
\hline & & 10 & mo & 0 & & mo & 0 \\
\hline & \multicolumn{2}{|l|}{ Eี } & \multicolumn{2}{|c|}{ 융 } & \multicolumn{3}{|c|}{ 号 } \\
\hline \multirow{6}{*}{$\begin{array}{l}\text { 음 } \\
\text { 햄 } \\
\text { 흘 }\end{array}$} & \multirow{2}{*}{ 离言 } & $\approx$ & 亏̊ సें & ڤें & & 웅 巳 & 通 \\
\hline & & 운 & -m. & 一 & & $0+$ & $\vec{m}$ \\
\hline & \multirow{2}{*}{ 菋 } & $\therefore$ & 용 & ㅇํํ & & 웅 & 官 \\
\hline & & 운 & +9 & $\sim$ & & 0 n & $\beth$ \\
\hline & \multirow[t]{2}{*}{ ڤั } & $\therefore$ & 8̊ㅇㅇㅇ & ᄋ̊․ & & ㅇㅇㅇ & ठ். \\
\hline & & 운 & ๓ 0 & 0 & & mo & 0 \\
\hline & 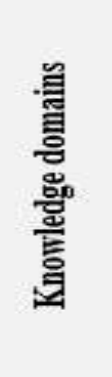 & & 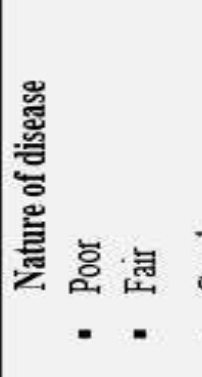 & $\begin{array}{l}\text { ठ্ర } \\
\text { - }\end{array}$ & 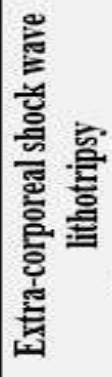 & - & $\begin{array}{l}\overrightarrow{8} \\
\text { - }\end{array}$ \\
\hline
\end{tabular}


Table (II): Cont.:

\begin{tabular}{|c|c|c|c|c|c|c|}
\hline & 邓® & & & . & & \\
\hline & 产 & $\therefore$ & & 홍 & & 흥 \\
\hline 흢 & & $\div$ & & $\approx 0$ & & $\curvearrowleft 0$ \\
\hline 홓 & 홍 & $\therefore$ & & 흥 응 & & 응 \\
\hline ํํㄹ & & 의 & & $\because 0$ & & mo \\
\hline 壱 & 足 & a & & 용 & & 응 \\
\hline & & 웅 & & no & & $\approx 0$ \\
\hline & E & & & $\stackrel{*}{\stackrel{*}{8}}$ & & 望客 \\
\hline & 产言 & $\therefore$ & & 亏̊ㅇㅇㅇㅎㅇ & & ㅎㅇㅇ응 \\
\hline 흠 & -8 & 윽 & & $0 \approx$ & & $0 \stackrel{n}{\circ}$ \\
\hline 苟 & ॅू & & & 今̊ & & ㅇㅎㅇ \\
\hline 펼 & & 으 & & 一古 & & 0 m \\
\hline 眞 & פั้ & $\therefore$ & & 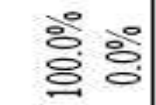 & & 응 응 \\
\hline & & 우 & & $\approx 0$ & & $\approx 0$ \\
\hline & 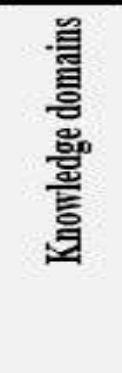 & & 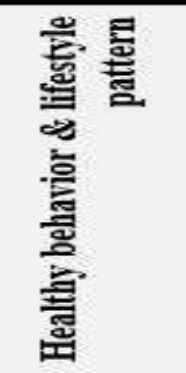 & $\begin{array}{l}\text { 总 固 } \\
\text { - - - }\end{array}$ & 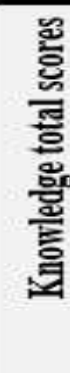 & $\begin{array}{l}\text { 莒缼 } \\
\text { - - }\end{array}$ \\
\hline
\end{tabular}


Table (III): Frequency distribution of the study and control group, according to their medical history of chronic diseases:

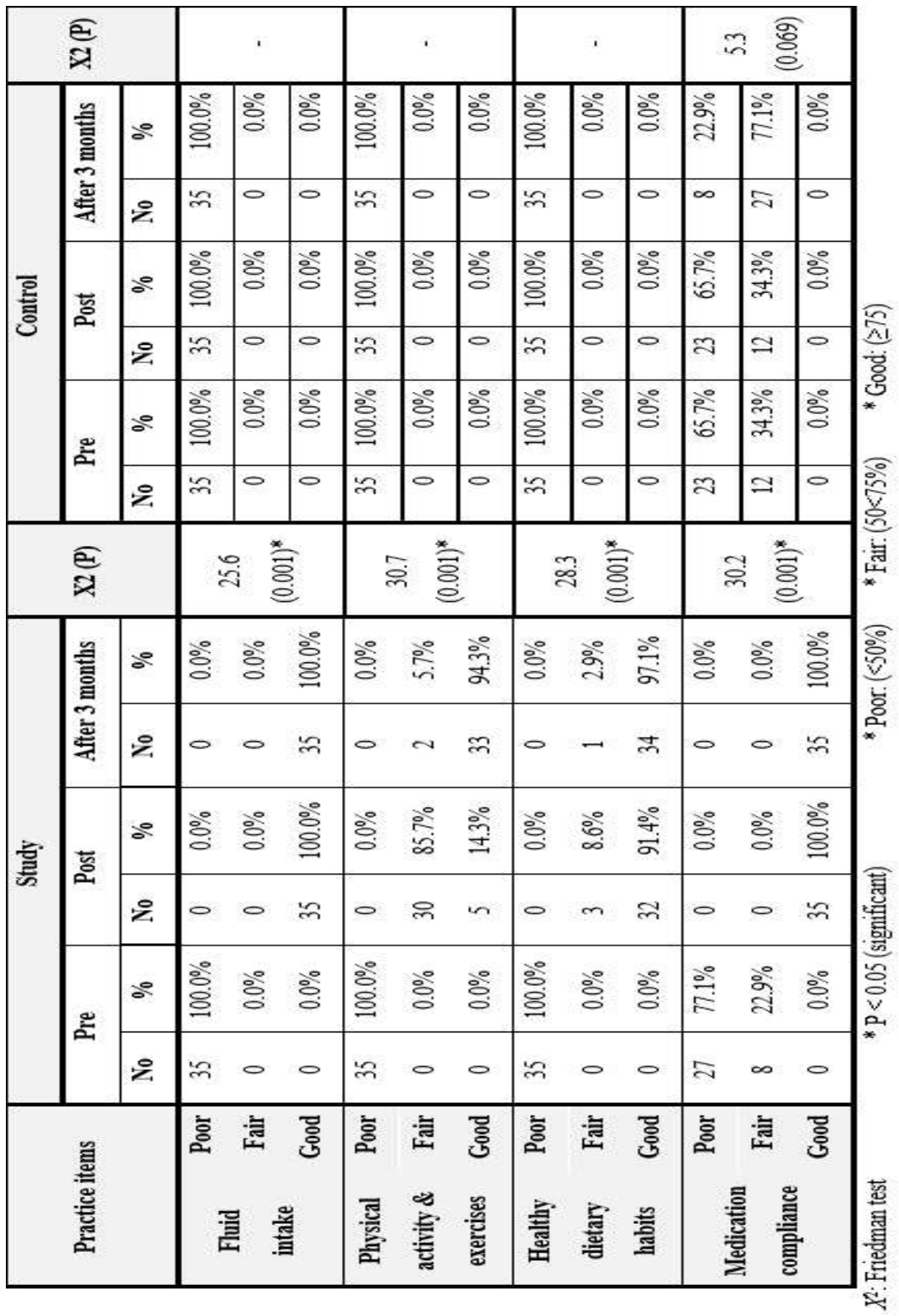


Table (III): Cont.:

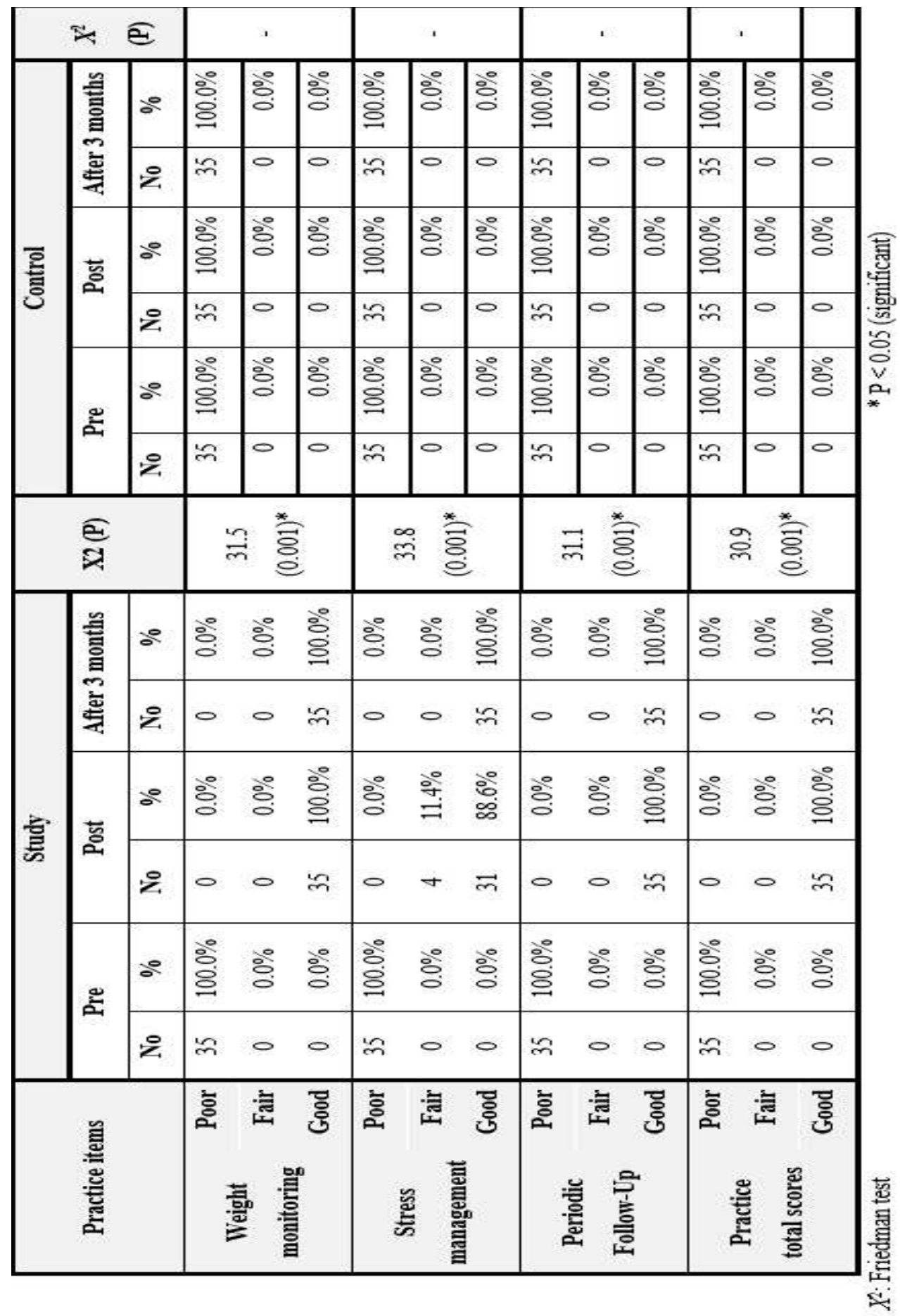


Table (IV) history of renal stone disease and family history:

\begin{tabular}{|c|c|c|c|c|c|c|c|}
\hline & & \multicolumn{2}{|c|}{ Pre } & \multicolumn{2}{|c|}{ Post } & \multicolumn{2}{|c|}{ After 3 months } \\
\hline & & \multicolumn{2}{|c|}{ Study } & \multicolumn{2}{|c|}{ Study } & \multicolumn{2}{|c|}{ Study } \\
\hline \multicolumn{2}{|c|}{ Demographicdata } & Mean & SD & Mean & SD & Mean & SD \\
\hline \multirow{2}{*}{ Gender } & Male & 9.47 & 4.39 & 131.24 & 8.15 & 135.29 & 4.00 \\
\hline & Female & 8.19 & 5.75 & 127.33 & 9.99 & 133.11 & 8.37 \\
\hline \multicolumn{2}{|c|}{ P\# } & \multicolumn{2}{|c|}{0.466} & \multicolumn{2}{|c|}{0.632} & \multicolumn{2}{|c|}{0.639} \\
\hline \multirow{5}{*}{ Age } & $21<30$ years & 8.80 & 6.81 & 126.00 & 6.34 & 133.20 & 6.70 \\
\hline & $30<40$ years & 10.72 & 4.35 & 130.85 & 9.46 & 137.38 & 6.05 \\
\hline & $40<50$ years & 8.67 & 2.80 & 130.83 & 6.11 & 137.33 & 2.73 \\
\hline & $50<=60$ & & & 129.50 & 14.95 & 134.33 & 10.29 \\
\hline & years & & & & & & \\
\hline \multicolumn{2}{|c|}{$\mathbf{P}$} & \multicolumn{2}{|c|}{0.136} & \multicolumn{2}{|c|}{0.216} & \multicolumn{2}{|c|}{0.336} \\
\hline \multirow{7}{*}{$\begin{array}{c}\text { Education } \\
\text { degree }\end{array}$} & Illiterate & 5.36 & 2.34 & 129.00 & 10.21 & 133.00 & 8.31 \\
\hline & Reads and & 8.00 & 4.34 & 129.83 & 13.33 & 134.67 & 6.68 \\
\hline & & & & 12117 & 650 & 12717 & 20 \\
\hline & Primary & 1.11 & 3.60 & קוגה & ك.0. & לגיסדי & 0.00 \\
\hline & Secondary & 10.93 & 3.11 & 127.44 & 8.47 & 132.67 & 6.96 \\
\hline & University \& & 20.00 & 3.61 & 130.33 & 7.57 & 136.00 & 4.36 \\
\hline & above & & & & & & \\
\hline \multicolumn{2}{|c|}{$\mathbf{P}$} & \multicolumn{2}{|c|}{$0.001 *$} & \multicolumn{2}{|c|}{0.960} & \multicolumn{2}{|c|}{0.704} \\
\hline \multirow{2}{*}{$\begin{array}{l}\text { Area of } \\
\text { residence }\end{array}$} & Rural & 6.80 & 3.41 & 128.65 & 10.68 & 134.10 & 7.36 \\
\hline & Urban & 11.49 & 5.82 & 130.00 & 7.12 & 134.27 & 5.71 \\
\hline \multicolumn{2}{|c|}{ P\# } & \multicolumn{2}{|c|}{$0.005^{*}$} & \multicolumn{2}{|c|}{0.675} & \multicolumn{2}{|c|}{0.942} \\
\hline
\end{tabular}


Table (IV): Cont.:

\begin{tabular}{|c|c|c|c|c|c|c|c|}
\hline & Single & 11.17 & 7.88 & & 6.86 & 134.50 & 5.36 \\
\hline Marital & Married & 7.94 & 3.92 & 129.50 & 9.64 & 133.86 & \\
\hline Status & Divorced & 19.00 & 0.0 & 139.00 & 0.0 & 141.00 & 0.00 \\
\hline & Widow & - & - & - & - & - & - \\
\hline & & $0 . c$ & & & & & 0.578 \\
\hline & Employed & 9.07 & 4.49 & 130.95 & 8.17 & 135.00 & 5.54 \\
\hline Fmnlovment & Unemployed & 24.00 & 0.0 & 127.00 & 0.0 & 134.00 & 0.00 \\
\hline status & Housekeeper & 7.23 & 4.25 & 126.62 & 10.81 & 132.85 & 8.35 \\
\hline & Retired & - & - & & & - & - \\
\hline & & 0.0 & & & & & \\
\hline Workplace & Outdoors & 6.94 & 3.80 & 131.81 & 8.92 & 135.94 & 7.19 \\
\hline area & Indoors & 10.39 & 5.60 & 127.05 & 9.14 & 132.68 & 5.87 \\
\hline & & 0.0 & & & & & \\
\hline Average & Enough & 15.33 & 8.08 & & & & 4.73 \\
\hline income & Not Enough & 8.20 & 4.45 & 133.84 & 6.73 & 133.84 & 6.73 \\
\hline & & 0.0 & & & & & \\
\hline
\end{tabular}

* $\mathrm{P}<0.05 \quad \mathrm{P}:$ One Way ANOVA

P\#: independent t-test(significant) 
Table (V): Frequency distribution of the study and control group, according to present history of stone characteristics and chief complaints:

\begin{tabular}{|c|c|c|c|c|c|c|c|}
\hline \multirow{2}{*}{\multicolumn{2}{|c|}{ Demographic data }} & \multicolumn{2}{|c|}{ Pre } & \multicolumn{2}{|c|}{ Post } & \multicolumn{2}{|c|}{ Post 3 months } \\
\hline & & Mean & SD & Mean & SD & Mean & SD \\
\hline \multirow{2}{*}{ Gender } & Male & .29 & .05 & 1.71 & .05 & 1.76 & .03 \\
\hline & Female & .27 & .03 & 1.63 & .05 & 1.75 & .04 \\
\hline \multicolumn{2}{|c|}{ P\# } & \multicolumn{2}{|c|}{0.130} & \multicolumn{2}{|c|}{$0.001 *$} & \multicolumn{2}{|c|}{0.773} \\
\hline \multirow{4}{*}{ Age } & $21<30$ years & .27 & .03 & 1.65 & .04 & 1.74 & .04 \\
\hline & $30<40$ years & .29 & .04 & 1.68 & .07 & 1.75 & .04 \\
\hline & $40<50$ years & .29 & .04 & 1.69 & .09 & 1.76 & .01 \\
\hline & $50<=60$ years & .26 & .03 & 1.68 & .03 & 1.77 & .05 \\
\hline \multicolumn{2}{|c|}{$\mathbf{P}$} & \multicolumn{2}{|c|}{0.217} & \multicolumn{2}{|c|}{0.476} & \multicolumn{2}{|c|}{0.593} \\
\hline \multirow{6}{*}{$\begin{array}{c}\text { Education } \\
\text { degree }\end{array}$} & Illiterate & .27 & .05 & 1.67 & .05 & 1.78 & .04 \\
\hline & Reads and & .30 & .04 & 1.71 & .07 & 1.74 & .04 \\
\hline & & & & & & & \\
\hline & Primary & .29 & U5 & 1.69 & .08 & 1.16 &.$U \angle$ \\
\hline & Secondary & .27 & .02 & 1.65 & .05 & 1.75 & .03 \\
\hline & $\begin{array}{l}\text { University \& } \\
\text { above }\end{array}$ & .26 & .02 & 1.62 & .08 & 1.73 & .06 \\
\hline \multicolumn{2}{|c|}{$\mathbf{P}$} & \multicolumn{2}{|c|}{0.519} & \multicolumn{2}{|c|}{0.196} & \multicolumn{2}{|c|}{0.197} \\
\hline \multirow{2}{*}{$\begin{array}{l}\text { Area of } \\
\text { residence }\end{array}$} & Rural & .27 & .04 & 1.68 & .06 & 1.76 & .04 \\
\hline & Urban & .29 & .04 & 1.67 & .07 & 1.75 & .04 \\
\hline \multicolumn{2}{|c|}{ P\# } & \multicolumn{2}{|c|}{0.326} & \multicolumn{2}{|c|}{0.617} & \multicolumn{2}{|c|}{0.386} \\
\hline
\end{tabular}


Table (5): Cont.:

\begin{tabular}{|c|c|c|c|c|c|c|c|}
\hline \multirow{4}{*}{$\begin{array}{l}\text { Marital } \\
\text { Status }\end{array}$} & Single & .27 & .04 & 1.63 & .04 & 1.74 & .05 \\
\hline & Married & .28 & .04 & 1.68 & .06 & 1.76 & .04 \\
\hline & Divorced & .26 & 0.0 & 1.69 & 0.0 & 1.79 & 0.0 \\
\hline & Widow & - & - & - & - & - & - \\
\hline \multicolumn{2}{|c|}{$\mathbf{P}$} & \multicolumn{2}{|c|}{0.724} & \multicolumn{2}{|c|}{0.145} & \multicolumn{2}{|c|}{0.393} \\
\hline \multirow{4}{*}{$\begin{array}{l}\text { Employment } \\
\text { status }\end{array}$} & Employed & .29 & .04 & 1.70 & .05 & 1.76 & .03 \\
\hline & Unemployed & .29 & 0.0 & 1.54 & 0.0 & 1.66 & 0.0 \\
\hline & Housekeeper & .26 & .03 & 1.63 & .04 & 1.75 & .04 \\
\hline & Retired & - & - & - & - & - & - \\
\hline \multicolumn{2}{|c|}{$\mathbf{P}$} & \multicolumn{2}{|c|}{0.146} & \multicolumn{2}{|c|}{$0.001 *$} & \multicolumn{2}{|c|}{$0.045^{*}$} \\
\hline \multirow{2}{*}{$\begin{array}{c}\text { Workplace } \\
\text { area }\end{array}$} & Outdoors & .28 & .05 & 1.68 & .07 & 1.76 & .03 \\
\hline & Indoors & .28 & .03 & 1.66 & .05 & 1.75 & .04 \\
\hline \multicolumn{2}{|c|}{ P\# } & \multicolumn{2}{|c|}{0.630} & \multicolumn{2}{|c|}{0.399} & \multicolumn{2}{|c|}{0.465} \\
\hline \multirow{2}{*}{$\begin{array}{c}\text { Average } \\
\text { monthly } \\
\text { income }\end{array}$} & Enough & .28 & .03 & 1.74 & .07 & 1.74 & .07 \\
\hline & Not Enough & .28 & .04 & 1.76 & .04 & 1.76 & .04 \\
\hline \multicolumn{2}{|c|}{ P\# } & \multicolumn{2}{|c|}{0.826} & \multicolumn{2}{|c|}{0.981} & \multicolumn{2}{|c|}{0.465} \\
\hline
\end{tabular}


Table (VI): Correlation between knowledge of the study group and their lifestyle pattern:

\begin{tabular}{|c|c|c|c|c|c|c|}
\hline \multirow{2}{*}{ Items } & \multicolumn{5}{|c|}{ Total lifestyle scores } \\
\cline { 2 - 7 } & \multicolumn{2}{|c|}{ Pre } & \multicolumn{2}{c|}{ Post } & \multicolumn{2}{c|}{ After 3months } \\
\cline { 2 - 7 } & r & P & r & P & r & P \\
\hline $\begin{array}{c}\text { Nature of the } \\
\text { disease }\end{array}$ & 0.055 & 0.753 & 0.662 & $0.001^{*}$ & 0.099 & 0.571 \\
\hline $\begin{array}{c}\text { Extra-corporeal } \\
\text { shock wave } \\
\text { lithotripsy }\end{array}$ & 0.308 & 0.072 & 0.667 & $0.002^{*}$ & 0.027 & 0.876 \\
\hline $\begin{array}{c}\text { Healthy behavior } \\
\text { \& lifestyle pattern }\end{array}$ & 0.049 & 0.779 & 0.665 & $0.009^{*}$ & 0.121 & 0.490 \\
\hline $\begin{array}{c}\text { Total knowledge } \\
\text { scores }\end{array}$ & 0.097 & 0.578 & 0.342 & $0.044^{*}$ & 0.027 & 0.878 \\
\hline
\end{tabular}

r: Pearson correlation coefficient

\section{REFERENCES}

1. Mohamed A. The Use of the Minimally Invasive Percutaneous Nephrolitholapaxy in the Management of Large Sized Upper Urinary Tract Calculi. Published Doctorate Dissertation. Faculty of Medicine, Assiut University, 2014.

2. Zainul A. Lonergan M. Lambert K. Renal stones - First steps and keys to reducing recurrence. Medicine Today Journal 2015; 16 (2): 45-52.

3. Sancak E, Mustafa R, Akbas A, Murat Tolga G, Muhammet A, Berkan R. Do Hypertension, diabetes mellitus and obesity increase the risk of severity of nephrolithiasis? Pakistan Journal of Medical Sciences 2015; 31(3): 566-71. 
4. Stuart J. Nephrolithiasis. 2015. Available at:

http://emedicine.medscape.com/article/437096-overview retrieved on February 2016.

5. Mustafa M. Study of Efficacy of Ultrasound-Guided Extracorporeal Shockwave Lithotripsy for Radiolucent Renal Stones. Published Master Thesis. Faculty of medicine Ain shams university. 2015

6. Richard E Miller Epidemiology for Health Promotion and Disease Prevention Professionals. 2nd ed. 2012. Routledge.P9-15.

7. Arelene L, Polastic L and Suzannee L. Care Principles and Practice of Medical, Surgical, Nursing" Web Sauders Company, Philadelphia, 6th ed, 2011, P 820-73.

8. Bogdana $\mathrm{K}$, et al. Systemic Implications of Urinary Stone Disease. The Translational Andrology and Urology Journal 2012; 1 (2): 89-96.

9. Kirkali Z, Rasooly R, Robert A. Griffin P. Urinary Stone Disease: Progress, Status, and Needs. Journal of Urology 2015; 86(4): 651-3.

10. Patel A et al. Epidemiological Characteristics of Renal Stone Patients Age (21-60) and Barriers in Their Dietary Modification in Saurashtra Region. International Journal of Research in Medical Sciences 2014; 2(1):80-3.

11. Naeem M, Muhammad H, Ahmad R, Muhammad A. Frequency of Renal Colic Due to Renal Stone Associated with Change in Climate During Different Months of the Year. Journal Of Saidu Medical College 2013; 3(2):383-8.

12. Knoll T et al. Urolithiasis through the Ages: Data on More Than 200,000 Urinary Stone Analyses. The Journal of urology 2011; 185(4):1304-11

13. Mawhoob $\mathrm{N}$ et al. Incidence of Renal Stone Disease among Urinary Tract Infection Patients and Antimicrobials Susceptibility. Advances in Applied Science Research Journal 2014; 5(3):309-14.

14. Shamsuddeen S. Risk Factors of Renal Calculi. Journal of Dental and Medical Sciences 2013; 11 (6): 90-5.

15. Devraj R, Matthew B, Vilay A. Relationship between Health Literacy and Kidney Function. Journal of Nephrology 2015; 20 (1) 360-7.

16. Gamal M, Assimos D, Sayed M. Prospective Randomized Trial of Extracorporeal Shock Wave Lithotripsy for Nephrolithiasis-Initial Results. The Journal of Urology 2010; 166(6):2072-80.

17. Glasheen J, Anderson M. Clinics review articles. An Issue of Hospital Medicine Clinics Elsevier Health Sciences 2016; 5 (1).

18. Shaaban B. Renal Stones Patients' Perception of the Occurrence of Renal Stones in Alex Main University Hospital. Unpublished Master Thesis 
2014. Alexandria University. Faculty of Nursing. Medical Surgical Nursing Department.

19. Peacock M, Robertson W, Schneider H, Vahlensieck W. Urolithiasis: Etiology. Diagnosis. Springer Science \& Business Media.2012.2nd ed.P255-65. 20. Pavithra c. Effectiveness of Structured Teaching Program on Knowledge Regarding Importance of Dietary Modification among Patients with Renal Calculi in a Selected Hospital, Bangalore. M.Sc. Nursing Dissertation. Rajiv Gandhi University of Health Sciences, Bangalore, Karnataka, College of Nursing, 2014.

21. Pietrow P, Preminger G. Management of Urolithiasis in elderly. Urology Textbook. 2011 9th ed. chap 43-P; 583-9.

22. Mohammed R. Impact of Health Education Program for Elderly Patients Undergoing Extracorporeal Shock waves Lithotripsy on Clearance of Urolithiasis. Journal of American Science 2015; 11(6):188-200.

23. Pietrow P, Preminger G. Management of Urolithiasis in elderly. Urology Textbook. 2011 9th ed. chap 43-P; 583-9.

24. Yilmaz A, Turgut Y. The Efficacy and Safety of ESWL in elderly. Journal of Gerontology 2011; 41(2):120-5.

25. Bos D, Abara E, Malvinder S. Knowledge, Attitudes, and Practice Patterns among Healthcare Providers in the Prevention of Recurrent Kidney Stones in Northern Ontario. Canadian Urological Association Journal 2014; 8(11-12):795-804.

26. Abid A. Success Factors of Extracorporeal Shock Wave Lithotripsy (ESWL) for Renal Calculi in Older adults, Baghdad, Iraq. Open Journal of Urology2014; 4(1): 26-32.

27. Weinman J, Keith J. Patients' Perceptions of Their Illness: The Dynamo of Volition in Health Care. Psychological Science Journal 2012; 21 (1): 60-5. 28. Abu Bakari A, et al. Associations between Knowledge, Illness Perceptions, Self-Management and Metabolic Control of Type 2 


\section{الملخص العزبي}

مقدمه: تعد حصوات الكلى واحدة من المشاكل الصحية الأكثر شيو عاً بين المرضى البالغين من حيث الإصابة و الوفيات، و العبء الاقتصادي، حيث تؤثر على 5-15٪ من السكان البالغين في جميع أنحاء العالم والتي تقدر بنحو 3\% لجميع الأفر اد على مدى الحياة للإنسان يعتبر مرض حصوات الكلى من أهم عوامل الخطر التي يمكن التحكم

بهاوخاصة للفشل الكلوي الحاد والمزمن، لذلك ينبغي أن يكون الهدف من علاج حصوات الكلى الكثف المبكر

و ونع حدوث المضاعفات والوقاية أو خفض معدل تكرار الإصابة به في المستقبل.ويعتبر تفتيت الحصوات

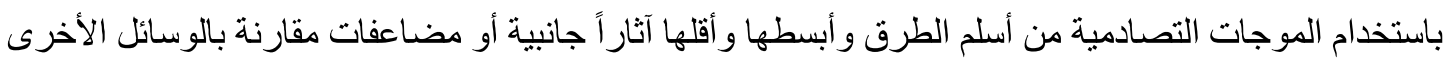
عندما يتم اتباع الإرشادات المناسبة، كما ويعتبر تعديل نمط الحياة بالإضافة إلى تفتيت الحصوات باستخدام

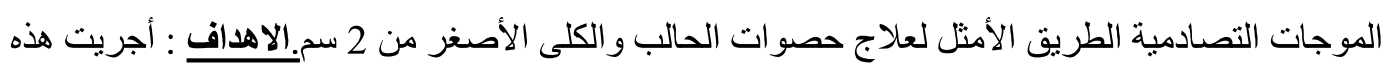
الدر اسة لتحديد تأثير تطبيق الإرشادات القائمة على الدلائل في تعديل نمط الحباة لمرضى حصوات الات الكلى البالغين الخاضعين لتفتيت الحصو ات بالموجات التصادمية.نوع البحث:تم استخدام تصميم البحوث شبه التجريبية في هذه الدر اسة

الطريقة : تضمنت الدراسة سبعون مريض بحصى الكلى من الفئة العمرية (21-60) سنة. واجريت في وحدة المسالك البولية بالمستشفى الرئيسي الجامعي بالاسكندرية ومركز النخبة الطبي للمسالك البولية بمدينة دمنهور من الفترة 1 مايو 2016م وحتى 30 ديسمبر 2016م ـ نم تقسيم المرضي الي مجمو عتين مجمو عه در اسه ومجمو عه ضابطة. وخضع جميع المرضى الى معرفه التاريخ المرضى العائلي و الفحص البدني بما في ذلك العمر, الجنس , التاريخ العائلي لحصوات الكلي و التاريخ الماضي من الحصوات المتكررة واي الامر اض الطبية الحالية بالاضافة الي تقييم معلومات وممارسات المرضي فيما يخص مرض حصوات الكلي و تفتيت الحصوات باستخدام الموجات التصادمية ومنع تكرار الاصابة مرة آخري. النتائج : أسفرت النتائج عن وجود ارتفاع ذو دلالة إحصائية واضحة في مستوى المعرفة وممارسات الحياة لدى الدى مجمو عة الدر اسة بعد تطبيق جلسات إرشادات تعديل نمط الحياة. ولهذا يعتبر إرشادات نعديل نمط الحياة تدخل غير دو ائي فعال للعلاج و الوقاية من تكر ار مرض حصوات الكلى: الاستتتاج استخلصت الدر اسة إلى أن جلسات إرشادات تعديل نمط الحياة أظهرت تأثير اً إيجابياً كبيراً في تحسين معرفة ونمط حياة المرضى في مجمو عة الدر اسة، فيما يخص جميع أنماط السلوكيات الصحية المتعلقة بمرض حصوات الكلي، ولهذا يعتبر إرشادات تعديل نمط الحياة تدخل غير دو ائي فعال للعلاج و الوقاية من تكرار مرض حصوات الكلى. مفاتيح الكلمات :تفتيت الحصو ات بالموجات التصادمية، حصوات الكلي، إرشادات نمط الحياة القائمة علي الدلائل. 